\title{
World Practice of State Support of the Tourism Sector in Foreign Countries in the Context of COVID-19
}

\begin{abstract}
Stanislau Arlou*
Perm State National Research University, Perm, Russia

*Corresponding author. Email: orlovstanislav1@rambler.ru

ABSTRACT

The problems of tourism sector development in different countries during the coronavirus pandemic are considered in this article. The purpose of this study is to examine government support measures in this sector in the context of COVID-19. In the pre-pandemic period the tourism industry was one of the main drivers of the development of the world economy and was most affected by the global crisis caused by the COVID-19 pandemic, therefore, effective government support of the tourism sector is currently a topical issue. The quality of tourism development directly depends on how the state assesses this industry, and, accordingly, how much it is stimulated by the state. In the course of the study it was concluded that the development of domestic tourism in foreign countries is currently a priority area of state support of the tourism sector. The necessity of supporting the tourism industry and promoting the demand for domestic tourism by Russian government has been substantiated.
\end{abstract}

Keywords: tourism industry, domestic tourism, coronavirus pandemic, government support.

\section{INTRODUCTION}

What implications does global tourism have and will continue to have in connection with the spread of the COVID-19 pandemic? What countries and regions of the world will suffer the biggest losses? What are the threats and advantages of the tourism crisis? What will the global crisis bring to the tourism industry? What innovative management anti-crisis measures should world governments and non-governmental organizations apply to overcome the unprecedented tourism crisis? All these questions remain relevant for the development of the tourism industry today and in future.

The coronavirus pandemic and the global crisis have caused significant damage to many sectors of the economy, including the tourism sector. The hospitality and restaurant sector is one of the worst hit by the pandemic. Trends in the development of the tourism industry were influenced not only by direct restrictions, such as introduction of quarantine measures, closure of borders, ban on visiting historical and cultural institutions, cancellation of air travel, but also indirect, i.e. measures that were taken in other tourism-related areas: restaurants and hotel business, transportation, film industry, sanatorium and medical services, etc.
The problem of tourism development is considered in the publications of many domestic and foreign scientists. The authors' attention is paid to the study and analysis of the development trends of both the domestic tourist market of the Russian Federation and the international one. Since the beginning of the coronavirus pandemic fell on the end of 2019, as well as due to the lack of official statistics, scientific sources have not yet sufficiently investigated the modern processes taking place in the tourist market in the context of the COVID-19 pandemic.

Among the domestic authors of studies who have devoted their publications to assessing the state of the tourism sector under the influence of COVID-19, the following should be distinguished: T.V. Solod [1] examined the state of the international travel business under the influence of changes caused by modern world challenges, analyzed the scenarios of development of the global tourism industry, made a forecast for recovery of travelling in the regions of the world; G.A. Simonyan, A.A. Saryan [2] identified the changes in the tourist market caused by the crisis, predicted a significant change in the structure of the Russian tourist market; V.G. Gulyaev, T.V. Rassokhina [3] considered the main anti-crisis strategies for sustainable tourism development as a response to the challenges formed by 
the COVID-19 pandemic for the tourism industry of the world and Russia, analyzed the main consequences for the economy, social sphere and consumer psychology, investigated structural changes in the tourism sector; M.A. Baeva and A.Yu. Knobel [4] analyzed the measures taken by countries or organizations to mitigate the consequences of the crisis caused by the coronavirus and restore the tourism and travel market, identified and substantiated the directions of adaptation measures to support and develop the tourism industry in current environment.

The tourism industry found itself in uncertain working conditions, which entailed significant changes in the functioning of tourism entities, which had to adapt to new business conditions, such as the introduction of new forms and types of tourism services, the development of additional measures to retain customers by postponing the provision of services, providing discounts and bonuses. Taking into account the fact that there is still no complete victory over the COVID-19 virus, the tourism industry facilities have to continue to look for ways to fight and maintain their share in the tourist market, find new methods to increase their competitiveness, and constantly improve the quality and safety of travel services, while being heavily dependent on government policies and measures taken to combat the coronavirus. That is why the issue of continuous research of the state and prospects of the tourism sector, taking into account new challenges caused by the coronavirus pandemic, becomes relevant.

Taking into account the consequences of COVID19 , it is necessary to introduce more effective directions for the development of the tourism industry, apply modern management concepts. It is necessary to combine technological factors, modern innovative mechanisms, significant intellectual resources, advantages of e-business, clustering of tourism development, development of promising types of tourism: business, green, rural, historical and cultural.

Experience of foreign countries convincingly confirms that the development of the tourism and recreation sector requires an effective state policy. First of all, this concerns the development of an appropriate legislative framework and the provision of financial and political stability in the country. Moreover, the state needs to have a positive image, to be active in presenting its own country at the international level, in particular, to open tourist information centers abroad.

\section{MATERIALS AND METHODS}

International and Russian statistical data, information from specialized business publications, cases of solutions to existing problems in the tourism industry in the context of new realities on the example of foreign countries served as the materials of the study. The methodological basis of the study was comprised of such scientific methods as collection, system analysis, comparison, and generalization.

In order to generalize the results, a comprehensive analysis of some of the activities carried out in the field of tourism at the state level in foreign countries was applied in order to develop a priority direction of state support for domestic tourism in Russia.

\section{RESULTS AND DISCUSSION}

The coronavirus pandemic has triggered an unprecedented crisis in the tourist economy. Due to the sharp drop in economic activity, workers in the tourism sector faced catastrophic reductions in working hours and job losses. Anti-epidemic measures taken for countering the spread of coronavirus have seriously limited movement of people, even within the countries where they live, not to mention travelling overseas. Since the beginning of quarantine measures, COVID-19 travel restrictions have been in effect in most countries of the world. On June 1, 2020, 156 governments completely closed their borders for international tourism. This was the reason for the fall in income in the field of tourism, both inbound and domestic. Among all global sectors of the economy, COVID-19 most strongly affected the tourism sector (about half of all financial losses); hotel and restaurant business, as well as air carriers suffered the most [5].

In the pre-pandemic period, tourism played a significant role in creating GDP in the economies of many countries, the contribution of the tourism industry to world GDP in 2019 was $10.4 \%$, in 2020 it decreased to $5.5 \%$ due to the coronavirus pandemic [6]. According to the World Travel \& Tourism Council, in 2020 the number of jobs in the tourism sector decreased by about 174 million [7].

There is no high-quality tourism statistics in Russia and tourism is not considered to be an important sector of the economy, unlike in many other countries. Tourism is usually not perceived as an economically important sector and is overlooked by the authorities. According to official statistics, tourism occupies a less significant place in the general economy of Russia, since it accounts for less than 5\% of GDP (in 2019 $4.9 \%$, in $2020-2.7 \%$ ) [6]. Russian tourism has not received a quick systemic response from the government in the form of introduction of possible measures to support the tourism industry compared to the response and types of measures introduced by governments of many foreign countries. Government support is a mandatory step for further development of the tourism sector.

The period from the end of 2019 till the beginning of 2020 became a turning point for the development of 
economies of many countries of the world and left a special imprint on the tourism industry. Countries one after another took measures to prevent the rapid spread of coronavirus disease, in particular, the ways of its transmission, and introduced quarantine restrictions. Closure of borders, ban on large gatherings of people and visits to public places led to deterioration in the financial condition and closure of a significant number of tourist facilities and decrease in tourist flows.

According to the World Tourism Organization, in the first five months of 2021 the situation with international tourism has become even worse than in 2020. Thus, last year the number of border crossings by tourists fell by $73 \%$ (about 1 billion) compared to 2019 . In January-May 2021, the drop was 85\% (460 million less) worldwide compared to the same period in 2019.

The decrease in the number of tourist arrivals was the most significant in the Asia-Pacific region: in 2020 this indicator fell by $84 \%$, and in January-May $2021-$ by $95 \%$. The least significant decrease in tourist flow was in America: by $68 \%$ in 2020 and by $72 \%$ in early 2021. The decrease in Europe was $68 \%$ in 2020 and $85 \%$ at the beginning of 2021 .

Since the beginning of the pandemic and the introduction of quarantine restrictions, it was difficult to predict travels and make plans for the future, it seemed that it would not be long and soon it would be possible to restore the regime. As a result, the tourism sector suffered losses and significant reduction in tourist flows. Countries needed to encourage foreign tourists and, at the same time, support the country's tourism-related facilities. Each country has developed and introduced measures to support the tourism industry (Table 1, own research based on [8], [9]).

\section{CONCLUSION}

Summarizing the aforementioned, we can conclude that tourism is one of those sectors of the global economy that has been hit hardest by the coronavirus pandemic. International travel activities in the context of today's dynamic changes in the global economy resulting from the spread of the coronavirus pandemic are accompanied by the increasing impact of inevitable specific risks. There is a need to develop an agreed algorithm of actions for both the leadership of travel companies and the state.

The main emphasis among the measures to stimulate and support the tourism industry in most countries is placed on domestic tourism, since the development of such direction as external tourism suffers more losses under the influence of the COVID-19 pandemic. Almost all countries are developing programs to stimulate and support the development of the tourism industry, including, in particular, support for small and mediumsized businesses by providing affordable credits, government loans and subsidies, deferred payment of debt obligations, providing tax holidays, incentives and reducing the rates on certain taxes. Tourism is supported by many governments for its opportunities to create jobs, generate income, improve the balance of payments and earnings of foreign currency. Tourism is considered to be an economical means of preserving and developing infrastructure, cultural environment and political stability.

Table 1. Measures on the improvement of tourist climate in the countries, stimulation and support of the tourism sector during the coronavirus pandemic and the post-pandemic period

\begin{tabular}{|l|l|}
\hline \multicolumn{1}{|c|}{ Country } & \multicolumn{1}{c|}{ Measures } \\
\hline China & $\begin{array}{l}\text { Conducted market research to predict the share of domestic tourism in total tourism demand. } \\
\text { Tourist activities are encouraged in each of the provinces. The Ministry of Culture and } \\
\text { Tourism together with the National Health Committee has called on provincial governments to } \\
\text { open local scenic places and attractions (with limited access under tightly controlled } \\
\text { conditions). }\end{array}$ \\
\hline $\begin{array}{l}\text { Iceland, Italy, Lithuania, the } \\
\text { Republic of Korea }\end{array}$ & $\begin{array}{l}\text { Approved travel vouchers issued by the government and provided to families for domestic } \\
\text { travel. }\end{array}$ \\
\hline Israel & Developed virtual on-line sightseeing tours across the country to stimulate the desire to travel. \\
\hline France & $\begin{array}{l}\text { Amended the cancellation policy for travel reservations allowing to replace refunds with cash } \\
\text { to vouchers for an equivalent amount. }\end{array}$ \\
\hline New Zealand & $\begin{array}{l}\text { Approved a special tourism support package, a part of which was dedicated to promoting } \\
\text { domestic tourism and preparing advertising campaigns in the domestic market. }\end{array}$ \\
\hline $\begin{array}{l}\text { Bosnia and Herzegovina, } \\
\text { Hungary, Malaysia, Mexico, } \\
\text { Thailand, Vietnam }\end{array}$ & $\begin{array}{l}\text { Prepared advertising and marketing campaigns, developed new products to attract } \\
\text { international tourists and support the development of domestic tourism. }\end{array}$ \\
\hline Japan & $\begin{array}{l}\text { Provided an emergency economic package that included a new subsidy of over 10 billion USD } \\
\text { for discounts and travel deals to consumers, thereby supporting tourism, transportation, food } \\
\text { services and business activities for an immediate recovery from the pandemic. After the } \\
\text { pandemic ends the Japan Tourism Agency will spend 2.2 billion USD on attracting tourists by } \\
\text { making tourism destinations attractive, improving travel environment and developing } \\
\text { promotions for international tourists. }\end{array}$ \\
\hline
\end{tabular}


There is a significant lag in the pace of implementation of government measures to support the tourism sector in Russia today which seriously threatens the competitiveness of the industry in the global market during the period of economic recovery in future. According to general estimates, the tourism industry will take 1.5-2 years to recover from the effects of the pandemic [5].

The prospects for tourism are highly uncertain and the recovery will depend on the interrelated effects of the economic and health crisis. These include the evolution of the pandemic, the presence and availability of a vaccine, control measures, the removal of travel restrictions, the survival and willingness of businesses across the tourism ecosystem to meet demand, and developments in the economy as a whole. The global scale and duration of the crisis, prolonged uncertainty and the interrelated economic and health-promoting nature of this crisis make it different from any previous shock to the tourism system.

In addition to the tourism crisis, the pandemic triggered a global economic crisis, which in turn has implications for tourism recovery. The road ahead is brighter as progress in vaccine production has given hope, but challenges remain and recovery will be uneven across countries and across sectors. Growth will pick up in many areas of the economy, but tourism and other sectors are recovering more slowly, and this affects recovery in many countries. It is too early to say what long-term impact the crisis will have on tourism, but the return to usual business is highly unlikely.

The longer the crisis lasts, the more businesses and jobs will be lost, the greater the impact on travel behavior and the tougher the economic and tourism recovery will be. It creates new challenges for the tourism industry, as well as opportunities to drive innovation, stimulate new business models, explore new niches and markets, discover new destinations and move towards more sustainable tourism development models.

Russia should also reconsider priorities aimed at overcoming the consequences of the crisis caused by the coronavirus pandemic and develop measures aimed at supporting and preserving the tourism industry. The design of support programs should be based on the principles of solidarity, competitiveness, sustainability, employment protection, income protection, and the participation of social partners.

Domestic tourism should be one of the potential consequences of a long-term tourism policy. Domestic tourism will be beneficial as people choose to stay at home and visit destinations within their own country. In addition, domestic tourism is less dependent on the global coronavirus crisis and quarantine measures.
Therefore, it is important to form our own Russian competitive tourist product and service.

The creation of Russian tourist destinations having the necessary tourist infrastructure and capable of providing high quality tourist services is an important task for domestic and inbound tourism development and regional economy recovery. There is an uneven development of the tourism industry in different regions in Russia today [10].

Russia has significant tourism potential and opportunities for the development of domestic tourism, the stimulation and maintenance of which will contribute to strengthening the country's image at the international level, which will help attract foreign tourists and minimize losses caused by the COVID-19 pandemic. Reorientation of tourists to the domestic market should contribute to the recovery of the country's tourism sector.

Finally, the territory of Russia is rich in historical and cultural attractions, natural and recreational resources and other specific resources that can be used in the tourism industry.

COVID-19 has demonstrated critical importance of the travel industry's need to adapt to changes quickly. A key shift for tourism development after COVID-19 is the government support for tourism actors at all stages of recovery from the crisis, as well as research to identify trends that can help tourism recover.

Well-developed and balanced policies to support tourism both at the state and regional levels will contribute to the development of not only this industry, but also the Russian economy as a whole.

\section{REFERENCES}

[1] T.V. Solod Scenarios of the Development of the World Tourism Industry in the Context of Global Instability, Economic Relations, 10(4) (2020) pp. 1011-1024.

DOI: https://doi.org/10.18334/eo.10.4.111324.

[2] G.A. Simonyan, A.A. Saryan On the Impact of the Coronavirus Pandemic on Tourism. Modern Scientific Thought, 2 (2020) pp. 158-164.

[3] V.G. Gulyaev, T.V. Rassokhina Sustainable Tourism Development under Crisis Conditions Caused by the COVID-19 Pandemic. Bulletin of the Russian International Academy of Tourism, 4 (2020) pp. 121-127.

[4] M.A. Baeva and A.Yu. Knobel Impact of the Pandemic on the Tourism Industry and Sports Events, Monitoring of the Economic Situation in Russia: Trends and Challenges of Social and Economic Development, 17(119) (2020) pp. 68-74. 
http://www.iep.ru/files/text/crisis_monitoring/2020 _17-119_June.pdf

[5] P.A. Kuchinov, COVID-19. The new world order in the tourism and travel industry, Iberoamerica (Russian Federation), 2021, pp. 28-50. DOI: https://doi.org/ 10.37656/s20768400-2021-1-02.

[6] Global Economic Impact Reports. Russian Federation 2021 Annual Research: Key Highlights. WTTC, 2021. https://wttc.org/Research/EconomicImpact/moduleId/704/itemId/192/controller/Downl oadRequest/action/QuickDownload

[7] Travel \& Tourism jobs could be lost due to COVID-19 and travel restrictions, says WTTC. WTTC, 2021. https://wttc.org/News-Article/174mTravel-\&-Tourism-jobs-could-be-lost-due-toCOVID-19-and-travel-restrictions

[8] World Tourism Organization (2020), UNWTO Briefing Note - Tourism and COVID-19, Issue 1 How are countries supporting tourism recovery?, UNWTO, Madrid, DOI: https://doi.org/10.18111/9789284421893.

[9] The COVID-19 crisis and tourism: Response and recovery measures to support the tourism sector in OECD countries. G20 Insights. https://www.g20insights.org/policy_briefs/the-covid-19-crisis-andtourism-response-and-recovery-measures-tosupport-the-tourism-sector-in-oecd-countries/

[10] M.A. Morozov, N.S. Morozova, Regional Features of Development of Tourism Infrastructure and Their Impact on Tourism. Regionology = Russian Journal of Regional Studies. 29(3) (2021) pp. 588610. DOI: https://doi.org/10.15507/24131407.116.029.202103.588-610. 